\title{
Light absorption of brown carbon aerosol in the PRD region of China
}

\author{
J.-F. Yuan, X.-F. Huang, L.-M. Cao, J. Cui, Q. Zhu, C.-N. Huang, Z.-J. Lan, and L.-Y. He
}

Key Laboratory for Urban Habitat Environmental Science and Technology, School of Environment and Energy, Peking University Shenzhen Graduate School, Shenzhen 518055, China

Correspondence to: X.-F. Huang (huangxf@pku.edu.cn)

Received: 2 September 2015 - Published in Atmos. Chem. Phys. Discuss.: 21 October 2015

Revised: 19 January 2016 - Accepted: 27 January 2016 - Published: 9 February 2016

\begin{abstract}
The strong spectral dependence of light absorption of brown carbon $(\mathrm{BrC})$ aerosol is regarded to influence aerosol's radiative forcing significantly. The Absorption Angstrom Exponent (AAE) method has been widely used in previous studies to attribute light absorption of $\mathrm{BrC}$ at shorter wavelengths for ambient aerosols, with a theoretical assumption that the AAE of "pure" black carbon (BC) aerosol equals to 1.0. In this study, the AAE method was applied to both urban and rural environments in the Pearl River Delta (PRD) region of China, with an improvement of constraining the realistic AAE of "pure" BC through statistical analysis of on-line measurement data. A threewavelength photo-acoustic soot spectrometer (PASS-3) and aerosol mass spectrometers (AMS) were used to explore the relationship between the measured AAE and the relative abundance of organic aerosol to $\mathrm{BC}$. The regression and extrapolation analysis revealed that more realistic $\mathrm{AAE}$ values for "pure" $\mathrm{BC}$ aerosol ( $\mathrm{AAE}_{\mathrm{BC}}$ ) were 0.86, 0.82, and 1.02 between 405 and $781 \mathrm{~nm}$, and $0.70,0.71$, and 0.86 between 532 and $781 \mathrm{~nm}$, in the campaigns of urban winter urban $_{\text {fall }}$, and rural $_{\text {fall }}$, respectively. Roadway tunnel experiments were conducted and the results further confirmed the representativeness of the obtained $\mathrm{AAE}_{\mathrm{BC}}$ values for the urban environment. Finally, the average light absorption contributions of $\mathrm{BrC}$ ( \pm relative uncertainties) at $405 \mathrm{~nm}$ were quantified to be $11.7 \%( \pm 5 \%), 6.3 \%( \pm 4 \%)$, and $12.1 \%( \pm 7 \%)$ in the campaigns of urban winter , urban $_{\text {fall }}$, and rural fall $_{\text {al }}$, respectively, and those at $532 \mathrm{~nm}$ were $10.0 \%( \pm 2 \%), 4.1 \%( \pm 3 \%)$, and $5.5 \%( \pm 5 \%)$, respectively. The relatively higher $\mathrm{BrC}$ absorption contribution at $405 \mathrm{~nm}$ in the rural $l_{\text {fall }}$ campaign could be reasonably attributed to the biomass burning events nearby, which was then directly supported by the biomass
\end{abstract}

burning simulation experiments performed in this study. This paper indicates that the $\mathrm{BrC}$ contribution to total aerosol light absorption at shorter wavelengths is not negligible in the highly urbanized and industrialized PRD region.

\section{Introduction}

Light absorbing carbonaceous aerosols including black carbon $(\mathrm{BC})$ and brown carbon $(\mathrm{BrC})$ are the primary matters absorbing light in the atmosphere. The importance of $\mathrm{BC}$ has been widely recognized in recent decades due to its effects of radiative forcing on climate change, while the role of $\mathrm{BrC}$ is far from being well known (Jacobson, 2001; Hansen et al., 1997; Haywood et al., 1997; Ramanathan and Carmichael, 2008; Gadhavi and Jayaraman, 2010; Wang et al., 2014). BrC is organic carbon which can absorb light based on a variety of chemical structures like nitrated and/or polycyclic aromatics, phenols, humic-like substances and biopolymers (Jacobson, 1999; Sun et al., 2011; Poschl, 2005). Main sources of $\mathrm{BrC}$ include biomass and biofuel burning, atmospheric humic-like substances (HULIS) from multiple phase actions, and photochemical oxidation of volatile organic compounds (VOCs) (Bond, 2001; Bergstrom et al., 2007; Alexander et al., 2015). South and East Asia are typical regions of atmospheric brown clouds (ABC) (Alexander et al., 2015). Biomass burning has been recognized as a significant contributor to $\mathrm{ABC}$, including forest burning, crop waste burning, traditional religious activities and residential burning in countries like India, China and Thailand (Venkataraman et al., 2006; Yan et al., 2006; Chakrabarty et al., 2013, 2014; Huang et al., 2012). BrC 
mainly absorbs light at UV and short-visible wavelengths (Chen and Bond, 2010; Kirchstetter et al., 2004; Lewis et al., 2008; Sandradewi et al., 2008; Schmid et al., 2006) and this strong spectral dependence has aroused more and more interest recently (Feng et al., 2013; Bahadur et al., 2012; Chung et al., 2012b; Wang et al., 2014; Jethva and Torres, 2011). $\mathrm{BrC}$ was ever estimated to contribute about $10-30 \%$ of total absorption of fine particles at shorter wavelengths, e.g. at 365 and $405 \mathrm{~nm}$, and contribute approximately $10 \%$ at midvisible wavelengths, e.g. at $532 \mathrm{~nm}$ (Bahadur et al., 2012; Lack et al., 2012b; Washenfelder et al., 2015; Nakayama et al., 2014). During an agricultural waste burning event, BrC aerosol could contribute more than $65 \%$ of light absorption at $370 \mathrm{~nm}$ and $15 \%$ at a mid-wavelength (Favez et al., 2009). However, the complexity and variety of molecular composition of $\mathrm{BrC}$ and the mixing state with other substances make it very challenging to study $\mathrm{BrC}$ optical properties (Alexander et al., 2015). Extensive experimental data from field studies are essential to evaluate light absorption by $\mathrm{BrC}$ as well as constraining and validating atmospheric and climate models.

There were two main methods to identify the absorption of $\mathrm{BrC}$ in total aerosol absorption at shorter wavelengths in previous studies: one was to use theoretical Mie models to calculate the light absorption of $\mathrm{BrC}$ with input of ambient chemical, physical, and optical measurements of bulk aerosol (Lack et al., 2012b); the other was based on optical measurement followed by absorption Angstrom exponent (AAE) calculation, which was actually simpler and widely used with a criterion of AAE for "pure" BC aerosol (AAE $\mathrm{BC}$ ) (Clarke et al., 2007; Favez et al., 2009; Yang et al., 2009; Bahadur et al., 2012; Chung et al., 2012a). The $\mathrm{AAE}_{\mathrm{BC}}$ has been commonly assumed to be 1.0 theoretically in many studies, but this simple assumption may not be reliable, and could cause a possible bias of the attributed absorption of $\mathrm{BC}$ from -22 to $+7 \%$ and then cause significant uncertainty of attributed $\mathrm{BrC}$ absorption (Lack and Langridge, 2013).

Some previous studies showed that ambient AAE was significantly affected by aerosol OC/EC (organic carbon / elemental carbon) ratio, suggesting a potentially important role of organic matter in aerosol light absorption (Utry et al., 2014). In this study, we tried to apply the AAE method to both urban and rural areas in the Pearl River Delta (PRD) region of China to attribute light absorption of $\mathrm{BrC}$, with an emphasis of exploring realistic $\mathrm{AAE}_{\mathrm{BC}}$ based on on-line measurements in field campaigns. The PRD region is one of the three economically developed regions of China and has been considered as one of the world's largest sources of anthropogenic soot emissions (Streets et al., 2001; Bond et al., 2004; Koch and Hasen, 2005). Despite strong emissions of BC aerosol in the highly urbanized and industrialized PRD region, the light absorption contribution of $\mathrm{BrC}$ aerosol should not be neglected without effective evaluation. Therefore, the focus of this paper was to reasonably quantify the light absorption of $\mathrm{BrC}$ aerosol in PRD with effective uncertainty evaluation using the AAE method.

\section{Experimental and data analysis methods}

\subsection{Sampling sites and periods}

Our measurements contained three field campaigns conducted in Shenzhen and Heshan in PRD during fall and winter, which are usually the polluted dry seasons of PRD with high frequency of haze episodes. The Shenzhen site (SZ) was an urban site in the southeast of the PRD region. It was on the campus of Peking University Shenzhen Graduate School $\left(22.60^{\circ} \mathrm{N}, 113.97^{\circ} \mathrm{E}\right)$, located in the west of Shenzhen, and the sampling periods were from 15 January to 19 February in the winter $\left(\operatorname{urban}_{\text {winter }}\right)$ and from 12 September to 9 October in the fall (urban $_{\text {fall }}$ ) in 2014. The Heshan site (HS) was a rural site $\left(22.71^{\circ} \mathrm{N}, 112.93^{\circ} \mathrm{E}\right), 40-50 \mathrm{~km}$ southwest to the megacity of Guangzhou in the central PRD. It was located on the top of a small hill with little local fossil fuel combustion emission nearby except biomass burning. The HS sampling period was from 1 to 22 November in the fall (rural fall) in 2014 and biomass burning events were observed occasionally as an obvious anthropogenic source in the nearby farmland.

In addition, tunnel experiments were also performed in Shenzhen in 2014 to explore the AAE values in a highly BC-polluted environment. We performed tunnel experiments three times in Shenzhen urban areas: twice in the Tanglangshan tunnel (TL) and once in the Jiuweiling (JW) tunnel. The sampling periods of the Tanglangshan tunnel were from 00:00 to 05:30 LT on both 16 and 18 October (as the TL1 and TL-2 experiments, respectively). The TL tunnel was $1.71 \mathrm{~km}$ in length with two channels that has three lanes in one direction for traffic, and the driving speeds in the tunnel were usually between 50 and $60 \mathrm{~km} \mathrm{~h}^{-1}$. The monitoring car was located $400 \mathrm{~m}$ in depth from the entrance. The sampling period of the JW tunnel was from 15:30 to 24:00 LT on 10 December (as the JW experiment). The JW tunnel was $1.45 \mathrm{~km}$ in length with two channels that has two lanes in one direction for traffic, and the driving speeds in the tunnel were usually about $60 \mathrm{~km} \mathrm{~h}^{-1}$. The monitoring car was located $800 \mathrm{~m}$ in depth from the entrance.

Moreover, since biomass burning is recognized as an important source of BrC (Ramanathan et al., 2007) and is a popular source in rural areas in PRD, especially during the harvest season (He et al., 2011; Zhang et al., 2013), we performed biomass burning simulation experiments in a combustion laboratory to study the spectral dependence of aerosol light absorption in biomass burning smoke. Different types of biomass materials, including straw, deciduous leaf, and firewood, were burned in two different combustion modes, i.e. stove burning and open burning, to simulate the traditional residential and field biomass burning. The combustion system in the laboratory included four parts: combustion simulation, dilution, tube sampling, and instrumental analyzing. The stove was built with bricks and mortar according to the local traditional structure. More detailed in- 
Table 1. The calibration results of PASS-3 in the campaigns.

\begin{tabular}{lccccc}
\hline Campaign & $\begin{array}{c}\text { Flow rate } \\
\left(\mathrm{L} \mathrm{min}^{-1}\right)\end{array}$ & $\begin{array}{c}\text { Error of laser } \\
\text { power_405 nm }\end{array}$ & $\begin{array}{c}\text { Error of laser } \\
\text { power_532 nm }\end{array}$ & $\begin{array}{c}\text { Error of laser } \\
\text { power_781 nm }\end{array}$ & Slope $\left(R^{2}\right)$ \\
\hline Urban $_{\text {winter }}$ & 0.97 & $0.6(\%)$ & $2.3(\%)$ & $2.5(\%)$ & $1.02(0.995)$ \\
Urban $_{\text {fall }}$ & 0.98 & $4.0(\%)$ & $1.1(\%)$ & $0.9(\%)$ & $1.03(0.996)$ \\
Rural $_{\text {fall }}$ & 0.98 & $2.5(\%)$ & $5.0(\%)$ & $3.6(\%)$ & $1.04(0.993)$ \\
Tunnel & 0.98 & $2.8(\%)$ & $4.3(\%)$ & $3.7(\%)$ & $1.07(0.993)$ \\
\hline
\end{tabular}

formation of the combustion system was described in our previous paper (He et al., 2010). Different biomass materials were burned inside the stove to simulate a complete water heating process referring to a standard protocol of water boiling test provided by the University of California (http://www.aprovecho.org/lab/pubs/testing). In addition, a certain amount of straw was piled up and burned on a pallet made of iron wire to simulate open burning of crop residues in the field.

\subsection{Instrumentation}

For the ambient sampling in this study, the instruments were placed in a temperature controlled room (or a monitoring car for the tunnel experiments), and the outdoor air was induced through a $\mathrm{PM}_{2.5}$ cyclone inlet placed on the rooftop and then dried before it entered the inlets of the instruments. A three-wavelength Photo-acoustic Soot Spectrometer (PASS3) (Droplet Measurement Technologies, CO, USA) was used to measure light absorption at 405,532 , and $781 \mathrm{~nm}$ with a data output time resolution of $2 \mathrm{~min}$. The principles and technical details of PASS-3 were described previously by Arnott et al. (1999). Then, we processed the 2 min time resolution data of absorption at three wavelengths for half hour averages and made further data analysis based on the half hour time resolution data sets. On the other hand, we also processed the 10-min time resolution data of organic aerosol derived from AMS or ACSM for half hour averages to explore the relationship with the absorption data sets.

A high-resolution time-of-flight aerosol mass spectrometer (HR-ToF-AMS) (Aerodyne Research, MA, US) was used to measure non-refractory species of $\mathrm{PM}_{1}$ including organic aerosol with a time resolution of $10 \mathrm{~min}$ at the SZ site. The detailed description of the instrument was given by DeCarlo et al. (2006), and the calibration followed the standard protocols (Jayne et al., 2000; Jimenez et al., 2003; Drewnick et al., 2005). More details about the HR-ToF-AMS operation were described in our previous publications (He et al., 2011; Huang et al., 2011). An aerosol chemical speciation monitor (ACSM) (Aerodyne Research, MA, US) was used at the HS site and in the tunnel experiments with a time resolution of $10 \mathrm{~min}$. In comparison with HR-ToF-AMS, ACSM was smaller and more convenient to be transported to field sampling sites and setup in a monitoring car with limited space. The detailed description of ACSM was given by $\mathrm{Ng}$ et al. (2011).

\subsection{Calibration of PASS-3}

The calibrations of PASS-3 for flow rate, laser power, and absorption were conducted following the standard procedures provided by the operational manual, which were also applied in relevant previous studies (Arnott et al., 2000; Lan et al., 2013; Nakayama et al., 2015). Firstly, the flow rate of sample air was calibrated by a soap film flow meter, with the results shown in Table 1; secondly, the laser power for each wavelength was calibrated by a laser power meter and the error in Table 1 indicated the reading difference between the laser power meter and the laser detector inside the instrument; thirdly, the light absorption calibration was performed by measuring highly absorbing $\mathrm{NO}_{2}(200 \mathrm{ppm})$ at $532 \mathrm{~nm}$. Then a good linear regression (with $R^{2}>0.99$ ) of the calculated extinction coefficient of $\mathrm{NO}_{2}$ and the measured light absorption was established. Since the scattering of gas is negligible, the extinction of $\mathrm{NO}_{2}$ should be very close to the absorption of $\mathrm{NO}_{2}$, and thus the slope of the fitting curve should be very close to 1 , as shown in Table 1 . The detection limit of aerosol light absorption with $2 \mathrm{~s}$ time resolution was 10,10 , and $3 \mathrm{Mm}^{-1}$ at 405,532 , and $781 \mathrm{~nm}$, respectively.

\subsection{Calculation of AAE and light absorption of BrC}

The AAE is an application of Angstrom exponent (Ångström, 1929) to describe the wavelength dependence of visible light absorption by aerosol, as expressed in Eq. (1):

$\mathrm{AAE}=-\ln \left(\operatorname{Abs}_{\lambda_{1}} / \mathrm{Abs}_{\lambda_{2}}\right) / \ln \left(\lambda_{1} / \lambda_{2}\right)$,

where Abs can be obtained by the absorption measurement and $\lambda$ represents a wavelength. The traditional AAE method for estimating $\mathrm{BrC}$ light absorption was described previously by Lack and Langridge (2013), and it can be expressed in Eqs. (2) and (3):

$$
\begin{aligned}
& \text { BC_Abs } \lambda_{\lambda_{1}}=\operatorname{Abs}_{\lambda_{2}} \times\left(\lambda_{2} / \lambda_{1}\right)^{\mathrm{AAE}_{\mathrm{BC}}} \\
& \mathrm{BrC}_{-} \mathrm{Abs}_{\lambda_{1}}=\mathrm{Abs}_{\lambda_{1}}-\mathrm{BC} \_\mathrm{Abs}_{\lambda_{1}},
\end{aligned}
$$

where $\mathrm{Abs}_{\lambda_{2}}$ is the measured absorption at a longer wavelength, at which $\mathrm{BrC}$ has negligible or no absorption. BC_Abs $\lambda_{\lambda_{1}}$ is the attributed absorption of BC at a shorter 
wavelength. BrC_Abs $\mathrm{Abs}_{\lambda_{1}}$ is thus the attributed absorption of $\mathrm{BrC}$ at the shorter wavelength. $\mathrm{AAE}_{\mathrm{BC}}$ is referred to as the AAE caused solely by "pure" BC aerosol, and is usually assumed to be 1.0 theoretically.

The total uncertainty of $\mathrm{BrC}_{-} \mathrm{Abs}_{\lambda_{1}}$ calculated $\left(U_{\mathrm{t}}\right)$ thus arises from both the absorption measurements and the $\mathrm{AAE}$ attribution method, and can be estimated by Eq. (4):

$U_{\mathrm{t}}=\sqrt{\left(U_{\mathrm{Abs} \_} \lambda_{1}\right)^{2}+\left(U_{\mathrm{Abs} \_} \lambda_{2}\right)^{2}+\left(U_{\mathrm{AAE}_{\mathrm{BC}}} \times \ln \left(\lambda_{2} / \lambda_{1}\right)\right)^{2}}$,

where $U_{\mathrm{Abs} \_\lambda_{1}}$ and $U_{\mathrm{Abs} \lambda_{2}}$ are the relative uncertainties of the absorption measured at $\lambda_{1}$ and $\lambda_{2}$, respectively; $U_{\mathrm{AAE}}$ is the absolute uncertainty of the $\mathrm{AAE}_{\mathrm{BC}}$ used, and needs to be multiplied by $\ln \left(\lambda_{2} / \lambda_{1}\right)$ to obtain the relative uncertainty of the AAE method. The uncertainty of the absorption measurement at a wavelength $\left(U_{\left.\mathrm{Abs}\right|_{\lambda}}\right)$ includes the fit to the absorption calibration slope, the electronic noise within the instrument (Lack et al., 2012a), as well as the drift correction of signals, and can be expressed as below:

$$
\begin{aligned}
& \Delta X=\sqrt[2]{\left(\Delta X_{\text {calibration }}\right)^{2}+\left(\Delta X_{\text {noise }}\right)^{2}+\left(\Delta X_{\text {drift }}\right)^{2}} \\
& U_{\text {Abs_ } \lambda}=\Delta X / \operatorname{Abs}_{\lambda},
\end{aligned}
$$

where $\Delta X$ calibration is derived from the uncertainty of the regression slope under a $95 \%$ confidence level $(p) ; \Delta X$ noise can be calculated through uncertainty propagation of noise equivalent absorption measured by PASS-3 every 2 min; $\Delta X$ drift is the standard deviation of the averaged baseline absorption of filtered air. Finally, $\Delta X$ is divided by $\operatorname{Abs}_{\lambda}$ to get the corresponding relative uncertainty $\left(U_{\mathrm{Abs} \_} \lambda\right)$. As a result, the relative uncertainties of the absorption measurements at the three wavelengths were $\sim 1.2 \%$ for the campaign of urban $_{\text {winter }}, 0.8-0.9 \%$ for the campaign of urban fall, and 1.5$1.6 \%$ for the campaign of rural ${ }_{\text {fall }}$.

\section{Results and discussion}

\subsection{Aerosol light absorption}

The time series of $\mathrm{PM}_{2.5}$ light absorption at three wavelengths in different campaigns were shown in Fig. 1. In the

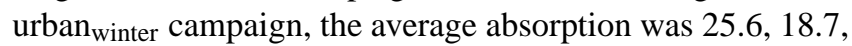
and $12.9 \mathrm{Mm}^{-1}$ at 405,532 , and $781 \mathrm{~nm}$, respectively. In the $\operatorname{urban}_{\text {fall }}$ campaign, the average absorption was 21.6, 16.2, and $11.8 \mathrm{Mm}^{-1}$ at 405,532 , and $781 \mathrm{~nm}$, respectively. It was seen that the aerosol absorbed more light in the winter, and its maximum absorptions were 162,122 , and $86.6 \mathrm{Mm}^{-1}$ at 405,532 , and $781 \mathrm{~nm}$, respectively, more than two times the maximum values in the fall. The higher aerosol pollution observed in the winter could be attributed to the unfavorable meteorological conditions in PRD in the winter, when the air mass came from the polluted northern continent with an overwhelming frequency and the atmospheric boundary layer became shallower due to lower ambient temperatures (Huang et al., 2014). In the rural fall $_{\text {campaign, the }}$ average absorption was $32.5,21.5$, and $14.6 \mathrm{Mm}^{-1}$ at 405 , 532, and $781 \mathrm{~nm}$, respectively, which were even higher than those of the urban winter $_{\text {and }}$ urban fall campaigns, but this was not strange since HS was a receptor site, suffering from the polluted air outflow from the northeast, where the megacity of Guangzhou was located, during the fall and winter seasons (Gong et al., 2012). The campaign-average ambient $\mathrm{AAE}_{405}$ 781 values ( \pm relative uncertainties) were calculated to be $1.05( \pm 0.01 \%), 0.92( \pm 0.10 \%)$, and $1.22( \pm 0.002 \%)$, respectively, for the urban winter $_{\text {, }}$ urban $_{\text {fall }}$, and rural fall $_{\text {cam- }}$ paigns, while those of $\mathrm{AAE}_{532 \_781}$ were $0.98( \pm 0.01 \%)$, $0.82( \pm 0.05 \%)$, and $1.00( \pm 0.001 \%)$, respectively. The corresponding uncertainties in the brackets were calculated through the uncertainty propagation of the absorption measurement uncertainties based on Eq. (1). The relatively higher values of $\mathrm{AAE}_{405 \_781}$ and $\mathrm{AAE}_{532 \_781}$ in the rural $\mathrm{fall}_{\text {fll }}$ campaign might be related to the biomass burning in the farmland surrounding the HS site.

It should be noted here that the contribution of dust particles to the aerosol light absorption was considered to be negligible in this study. Firstly, there was no dust event during the three campaigns; secondly, organic aerosol typically contributes $>30 \%$ of $\mathrm{PM}_{2.5}$ mass in both urban and rural environments, far higher than that of the dust $(<5 \%)$ (Huang et al., 2014). Considering that the mass absorption efficiency (MAE) values of dust at shorter and mid-visible wavelengths are lower than those of organic aerosol by a magnitude of one or two (Favez et al., 2009; Yang et al., 2009), the light absorption contribution of dust could be negligible in comparison with that of organic aerosol in PRD. Therefore, light absorption of dust was not taken into account in the following discussion.

\subsection{Determination of the AAE for "pure" $\mathrm{BC}$ aerosol}

Theoretically, the AAE for "pure" $\mathrm{BC}$ aerosol $\left(\mathrm{AAE}_{\mathrm{BC}}\right)$ is assumed to be 1.0 (Lack and Langridge, 2013), and $\mathrm{BrC}$ absorption at shorter wavelengths can raise this value in ambient atmosphere. In this study, we explored more realistic $\mathrm{AAE}_{\mathrm{BC}}$ in PRD by establishing a univariate regression relationship for each campaign, as shown in Fig. 2. In each campaign, the organic aerosol mass concentration was measured by AMS or ACSM, and the absorption at $781 \mathrm{~nm}\left(\mathrm{Abs}_{781 \mathrm{~nm}}\right)$ could be used to represent the $\mathrm{BC}$ amount since $\mathrm{BrC}$ had negligible absorption at longer wavelengths (Kirchstetter et al., 2004; Lack and Langridge, 2013; Lack et al., 2012b). Then, $r_{\text {org/bc }}$ (the ratio of organic aerosol mass concentration to $\mathrm{Abs}_{781 \mathrm{~nm}}$ ) was used as an index of the relative abundance of organic aerosol to BC. In our campaigns, $r_{\text {org }} / \mathrm{bc}$ was a simpler while more effective index than other similar indices like the mass ratio of $\mathrm{OC} /(\mathrm{OC}+\mathrm{EC})$, calculating which needed to assume a mass absorption efficiency for the measured light absorption data and correct the cutoff size difference 

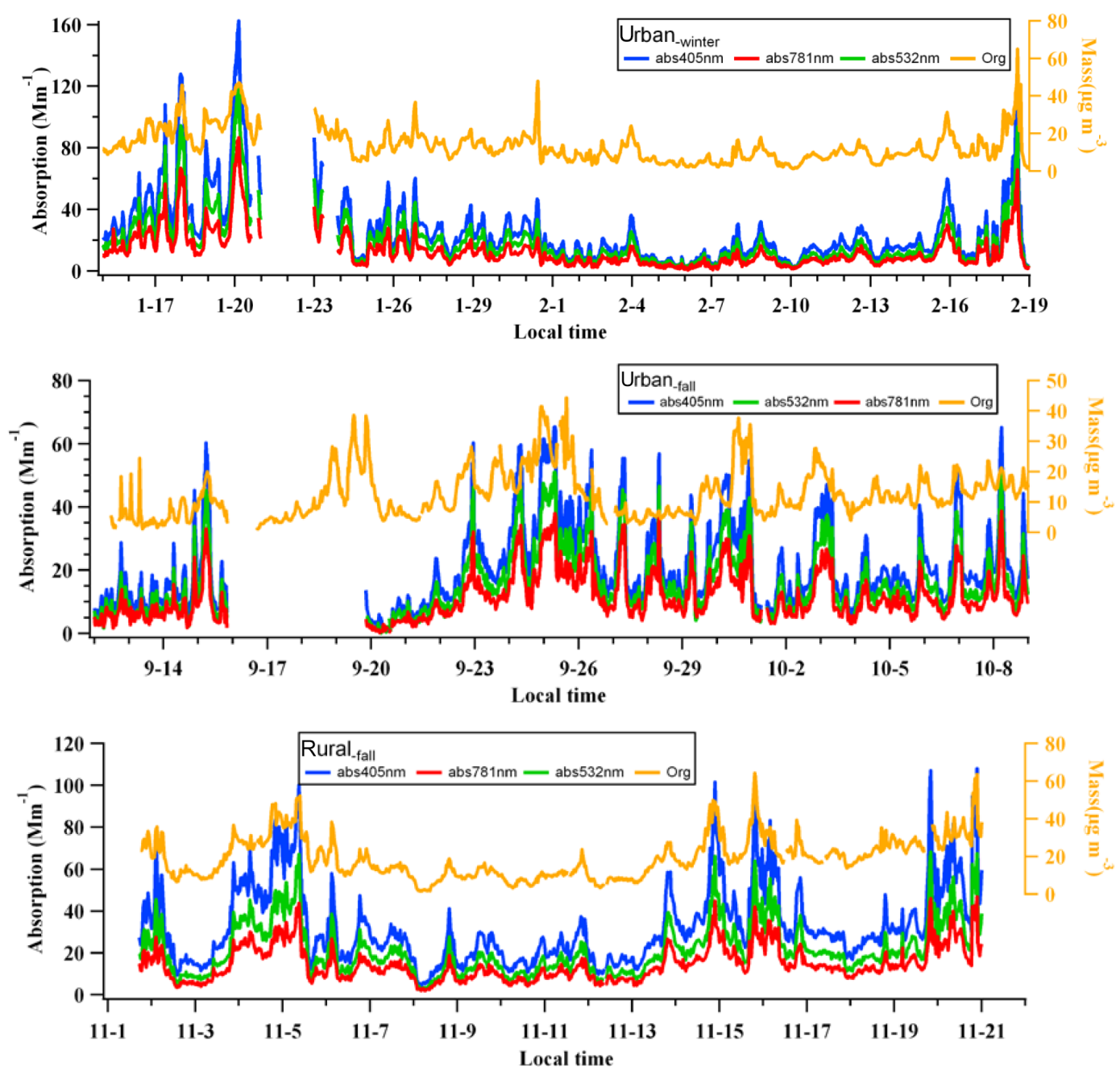

Figure 1. The time series of aerosol light absorption and mass concentration of organic aerosol in the different campaigns.

for PASS-3 $\left(\mathrm{PM}_{2.5}\right)$ and AMS/ASCM $\left(\mathrm{PM}_{1}\right)$ sampling. Finally, the $\mathrm{AAE}_{405} 781$ and $\mathrm{AAE}_{532}$ 781 were plotted versus the $r_{\text {org/bc }}$ averaged within equal intervals for each campaign in Fig. 2, with the corresponding linear fitting curves.

For all the campaigns, the linear relationships between $\mathrm{AAE}_{405}$ 781 (or $\mathrm{AAE}_{532 \_781}$ ) and $r_{\text {org/bc }}$ were significant enough with correlation coefficients $\left(R^{2}\right)$ of $0.59-0.98$, indicating AAE was positively related with the relative amount of organic matter, which certainly included BrC. Utry et al. (2014) also revealed a strong correlation between AAE and aerosol OC/EC at an urban site in Hungary, where OC was mainly emitted from wood burning and contained a large amount of BrC. The intercepts of the fitting curves in Fig. 2, where $r_{\mathrm{org} / \mathrm{bc}}=0$, can be regarded as the situation for "pure" $\mathrm{BC}$ without any organic matter, and thus are suitable proxies of the $\mathrm{AAE}_{\mathrm{BC}}$ values for the different campaigns. The uncertainties of the regression intercepts represent the absolute uncertainties of the $\mathrm{AAE}_{\mathrm{BC}}\left(U_{\mathrm{AAE}_{\mathrm{BC}}}\right)$, and can be calculated following Eq. (7):
$U_{\mathrm{AAE}_{\mathrm{BC}}}=t_{p} \times S(a)$,

where $S(a)$ represents the standard deviation of the regression intercept $(a)$ calculated by the SPSS software, and $t_{p}$ is determined by the $t$ distribution list according to a confidence level ( $p$ ), which was set to be $95 \%$ in this study.

The calculated $\mathrm{AAE}_{\mathrm{BC}}$ values and corresponding uncertainties at 405 and $532 \mathrm{~nm}$ were summarized in Table 2, and they were found similar in the urban winter $(0.86 \pm 0.06$ and $0.70 \pm 0.05)$ and urban fall $(0.82 \pm 0.06$ and $0.71 \pm 0.06)$ campaigns, but were higher in the rural fall campaign $(1.02 \pm 0.10$ and $0.86 \pm 0.13)$. The difference of the $\mathrm{AAE}_{\mathrm{BC}}$ between the urban site and rural site might result from different sources of BC aerosol. Fossil fuel combustion, e.g. vehicle emissions, was indicated to be the dominant source of BC aerosol in urban Shenzhen (Lan et al., 2011), while biomass burning emissions played an important role in the fall at the rural HS site (Gong et al., 2012). In PRD, Lan (2013) found that the BC diameters of both vehicular 

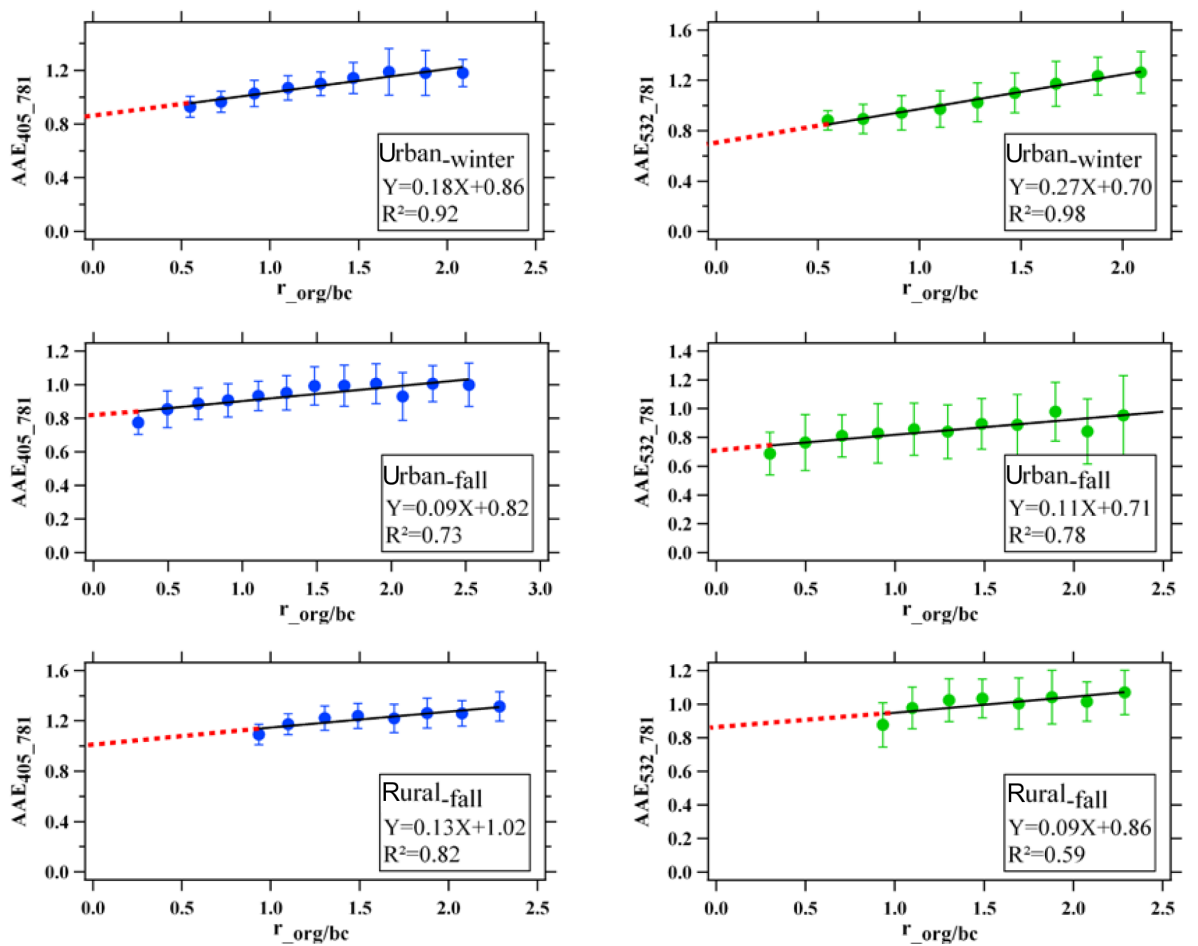

Figure 2. The linear relationship between AAE and $r_{\mathrm{org} / \mathrm{bc}}$ in the different campaigns.

Table 2. The derived $A A E_{B C}$ values and uncertainties in the different campaigns.

\begin{tabular}{|c|c|c|}
\hline Campaign & $\mathrm{AAE}_{405 \_781}$ & $\mathrm{AAE}_{532 \_781}$ \\
\hline Urban & $0.86 \pm 0.06$ & $0.70 \pm 0.05$ \\
\hline $\mathrm{Urban}_{\text {fall }}$ & $0.82 \pm 0.06$ & $0.71 \pm 0.06$ \\
\hline Rural $_{\text {fall }}$ & $1.02 \pm 0.10$ & $0.86 \pm 0.13$ \\
\hline
\end{tabular}

exhaust and biomass burning were generally above $100 \mathrm{~nm}$, using a single particle soot photometer to measure, and the $\mathrm{BC}$ diameters of vehicular emissions were even larger. On the other hand, Gyawali et al. (2009) found that the AAE value would decrease as the $\mathrm{BC}$ diameter increases in the range of $0.1-1 \mu \mathrm{m}$ by theoretical modeling. Therefore, the larger $\mathrm{AAE}_{\mathrm{BC}}$ obtained at the rural site could be a result of the smaller BC diameters of biomass burning in PRD.

It should be noted that previous studies showed that AAE of ambient aerosol can also be influenced by a couple of other factors, such as size distribution, mixing state, and fractal dimension of BC particles (Levin et al., 2010; Gyawali et al., 2009; Scarnato et al., 2013; Bond and Bergstrom, 2006), but it is quite complicated and almost impossible to consider the influence of all these factors simultaneously. Scarnato et al. (2013) also pointed out that it is very difficult to clarify the relationship between AAE and aerosol morphology and mixing state due to quite complicated mechanisms in real cases. In this study, this issue was just simplified using a univari- ate regression analysis to explore the relationship between ambient AAE and organic aerosol. As a result, the good correlations obtained in Fig. 2 indicated that $\mathrm{BrC}$ itself could be the dominant factor leading to the variation of $\mathrm{AAE}$, and thus the extrapolated intercept was a good surrogate for $\mathrm{AAE}_{\mathrm{BC}}$. The influence of other factors could be partly reflected by the error bars of the data points in Fig. 2 and the estimated uncertainty of the intercept (i.e. $U_{\mathrm{AAE}_{\mathrm{BC}}}$ ).

\subsection{AAE measurements of primary emission sources}

\subsubsection{Roadway tunnel experiments}

Since the major primary source of $\mathrm{BC}$ in urban environment in PRD was proved to be vehicular exhaust (Yuan et al., 2006; Huang et al., 2006; Lan et al., 2013), we performed three roadway tunnel experiments in urban Shenzhen, in order to verify the representativeness of the $\mathrm{AAE}_{\mathrm{BC}}$ derived from the urban atmosphere. The tunnel air measurement results were presented in Fig. 3. Since the tunnel air was largely dominated by fresh BC particles, the observed $r_{\text {org/bc }}$ values were found in a lower range (0.2-0.8) in comparison with those in the urban atmosphere, and thus the extrapolation of the linear regression in Fig. 3 could get more reliable intercepts, i.e. $\mathrm{AAE}_{\mathrm{BC}}$. As summarized in Table 3, the $\mathrm{AAE}_{\mathrm{BC}}$ values obtained at 405 and $532 \mathrm{~nm}(0.80-0.89$ and $0.63-0.72$, respectively) in the tunnel experiments well confirmed the 

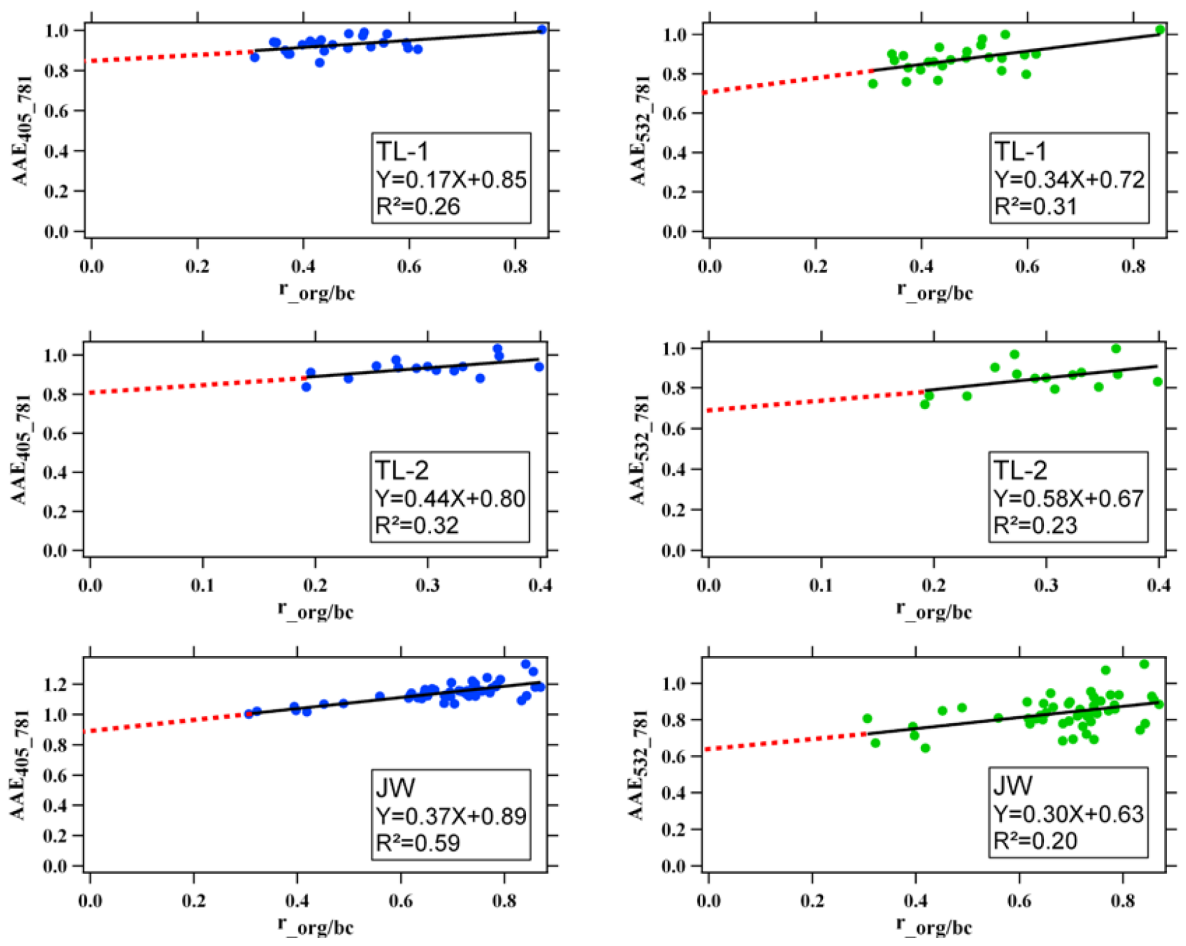

Figure 3. The linear relationship between $\mathrm{AAE}$ and $r_{\mathrm{org} / \mathrm{bc}}$ in the tunnel experiments.

$\mathrm{AAE}_{\mathrm{BC}}$ values derived from the ambient measurements in urban Shenzhen.

\subsubsection{Biomass burning simulation experiments}

The AAE values with standard deviations of different types of biomass burning were presented in Table 4. It was found that the absorption generally showed large spectral dependence and the AAE varied among different biomass types or combustion modes, with $\mathrm{AAE}_{405-532}$ ranging from 2.1 to 8.3, $\mathrm{AAE}_{532-781}$ ranging from 1.3 to 5.0, and $\mathrm{AAE}_{405-781}$ ranging from 1.7 to 6.2 , significantly higher than those observed in the ambient air and tunnel air. Therefore, the higher AAE values observed for biomass burning particles, especially between 405 and $532 \mathrm{~nm}$, proved that biomass burning was a significant contributor to absorption at shorter wavelengths in the rural ${ }_{\text {fall }}$ campaign. In the combustion mode of stove burning, the leaves tended to emit more $\mathrm{BrC}$ than wood, stalk, and straw, which should be a result of their different biomass chemical nature. Besides, the AAE values of short straw were a few times higher in open burning than in stove burning, which could be explained by that it was easier to cause a hypoxic environment in smoldering and a larger amount of yellow fume was produced (Einfeld et al., 1991; Patterson and McMahon, 1984; Kirchstetter et al., 2004; Chakrabarty et al., 2010).
Table 3. The derived $A A E_{B C}$ values and uncertainties in the tunnel experiments.

\begin{tabular}{lcc}
\hline Tunnel & AAE $_{405 \_781}$ & AAE $_{532 \_781}$ \\
\hline TL-1 & $0.85 \pm 0.06$ & $0.72 \pm 0.10$ \\
TL-2 & $0.80 \pm 0.11$ & $0.68 \pm 0.19$ \\
JW & $0.89 \pm 0.06$ & $0.63 \pm 0.12$ \\
\hline
\end{tabular}

\subsection{Quantification of light absorption of $\mathrm{BrC}$}

Based on the well determined $\mathrm{AAE}_{\mathrm{BC}}$ and $\mathrm{Abs}_{781 \mathrm{~nm}}$ in the three field campaigns, we could finally calculate the light absorption of $\mathrm{BrC}$ at 405 and $532 \mathrm{~nm}$ according to Eq. (3). As a result, the average light absorption of $\mathrm{BrC}$ at $405 \mathrm{~nm}$ was $3.0,1.4$, and $3.9 \mathrm{Mm}^{-1}$ in the urban winter, , urban $_{\text {fall }}$, and rural fall campaigns, respectively, contributing $11.7 \%( \pm 5 \%), 6.3 \%( \pm 4 \%)$, and $12.1 \%( \pm 7 \%)$ of the total aerosol light absorption, respectively. Here, the values in the brackets were the relative uncertainties calculated through Eq. (4). The average light absorption of $\mathrm{BrC}$ at $532 \mathrm{~nm}$ was $1.9,0.7$, and $1.2 \mathrm{Mm}^{-1}$ in the urban winter, , urban $_{\text {fall }}$, and rural fall campaigns, respectively, contributing $10.0 \%( \pm 2 \%), 4.1 \%( \pm 3 \%)$, and $5.5 \%( \pm 5 \%)$ of the total aerosol light absorption, respectively.

The results indicated that no matter at the urban site or rural site in PRD, BC still played a dominant role in total aerosol light absorption at 405 and $532 \mathrm{~nm}$, but the contribu- 
Table 4. The AAE values observed in the biomass burning simulation experiments.

\begin{tabular}{lcccc}
\hline Biomass type & Burning modes & AAE $_{\text {405_532 }}$ & AAE $_{532 \_781}$ & AAE $_{405 \_781}$ \\
\hline Short straw & Open burning & $8.27 \pm 1.34$ & $4.96 \pm 1.15$ & $6.20 \pm 1.33$ \\
Ficus microcarpa leaf & Stove burning & $5.85 \pm 1.69$ & $3.46 \pm 0.96$ & $4.46 \pm 1.20$ \\
Lychee leaf & Stove burning & $4.90 \pm 1.61$ & $2.52 \pm 1.07$ & $3.48 \pm 1.20$ \\
Corn stalk & Stove burning & $3.83 \pm 1.49$ & $2.39 \pm 1.06$ & $2.97 \pm 1.16$ \\
Litchi wood & Stove burning & $3.55 \pm 1.50$ & $1.95 \pm 0.85$ & $2.61 \pm 1.00$ \\
Eucalyptus wood & Stove burning & $2.34 \pm 0.85$ & $1.30 \pm 0.53$ & $1.71 \pm 0.50$ \\
Short straw & Stove burning & $2.32 \pm 0.65$ & $1.39 \pm 0.47$ & $1.76 \pm 0.25$ \\
Peanut stalk & Stove burning & $2.13 \pm 1.01$ & $2.08 \pm 0.86$ & $1.99 \pm 0.50$ \\
\hline
\end{tabular}

tion of $\mathrm{BrC}$ was not negligible, with a fraction of up to $12 \%$. The higher $\mathrm{BrC}$ contribution in the urban $_{\text {winter }}$ campaign than

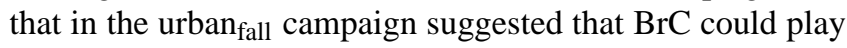
a more important role in polluted continental air mass, since Shenzhen had a higher frequency of continental air mass from the north than that of marine air mass from the south in winter. On the other hand, the highest $\mathrm{BrC}$ contribution

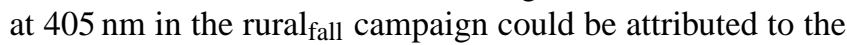
influence of biomass burning in the farmland nearby, which was supported by the biggest difference of $\mathrm{BrC}$ absorption between 405 and $532 \mathrm{~nm}$ : the $\mathrm{AAE}_{405} 532$ of $\mathrm{BrC}$ was calculated to be $1.7,2.5$, and 4.3 for the campaigns of urban ${ }_{\text {winter, }}$, urban $_{\text {fall, }}$, and rural fall, respectively. High AAE 405 532 was found to be a feature in the biomass burning simulation experiments, as in Table 4. Especially strong absorption at $404 \mathrm{~nm}$ of biomass burning-emitted $\mathrm{BrC}$ was also found by Lack et al. (2012b). The lowest $\mathrm{AAE}_{405} 532$ of the urban ${ }_{\text {winter }}$ campaign indicated that fossil fuel combustion, rather than biomass burning, seemed to be the major source of $\mathrm{BrC}$ in Shenzhen in winter.

Finally, it should be noted that it is unwise to calculate the light absorption contribution of $\mathrm{BrC}$ at a specific time during the field campaigns, since the $\mathrm{AAE}_{\mathrm{BC}}$ derived for the whole case of a single campaign could have a large bias from the real $\mathrm{AAE}_{\mathrm{BC}}$ at that time, due to variations of the influencing factors, e.g. size distribution, mixing state, and morphology of $\mathrm{BC}$ particles.

\section{Conclusions}

In this study, an improved AAE method was used to estimate the light absorption of $\mathrm{BrC}$ at an urban site and a rural site in the PRD region of China in polluted seasons during 2014, based on ambient on-line measurements using PASS-3 and AMS (or ACSM). The obtained ambient $\mathrm{AAE}_{405} 781$ averages were $1.05,0.92$, and 1.22 in the three campaigns of urban $n_{\text {winter }}$, urban $_{\text {fall }}$, and rural fall, respectively, while those for $\mathrm{AAE}_{532}$ 781 were 0.98, 0.82, and 1.00, respectively. The linear regression between AAE $405 \_781$ (or $\mathrm{AAE}_{532}$ 781) and the ratio of organic aerosol to $\mathrm{BC}$ resulted in reasonable intercepts, which were assumed to be the AAE for "pure" $\mathrm{BC}\left(\mathrm{AAE}_{\mathrm{BC}}\right)$. The obtained $\mathrm{AAE} B \mathrm{BC}$ values between $405-781 \mathrm{~nm}$ were $0.86,0.82$, and 1.02 in the campaigns of urban $_{\text {winter }}$, urban fall $_{\text {, and }}$ rural $_{\text {fall }}$, respectively, and those between $532-781 \mathrm{~nm}$ were $0.70,0.71$, and 0.86 , respectively. These $\mathrm{AAE}_{\mathrm{BC}}$ values were believed to be more realistic in PRD than the theoretical default value of 1.0. The results of the tunnel experiments further confirmed that the realistic $\mathrm{AAE}_{\mathrm{BC}}$ values in the urban atmosphere should be within the ranges of $0.8-0.9$ between 405 and $781 \mathrm{~nm}$ and of $0.6-0.7$ between 532 and $781 \mathrm{~nm}$. As a result, the average $\mathrm{BrC}$ light absorption contributions ( \pm relative uncertainties) at $405 \mathrm{~nm}$ were quantified to be $11.7 \%( \pm 5 \%), 6.3 \%( \pm 4 \%)$, and $12.1 \%( \pm 7 \%)$ in the campaigns of urban winter $_{\text {, }}$ urban $_{\text {fall }}$, and rural $_{\text {fall }}$, respectively, and those at $532 \mathrm{~nm}$ were $10.0 \%( \pm 2 \%), 4.1 \%( \pm 3 \%)$, and $5.5 \%( \pm 5 \%)$, respectively. It was found that $\mathrm{BrC}$ played a more important role in more polluted winter or in the rural area with intensive biomass burning in PRD. Although BC still played a dominant role in total aerosol light absorption in $\mathrm{PRD}$, the contribution of $\mathrm{BrC}$ at shorter wavelengths was not negligible, with a percent of up to $>10 \%$.

Acknowledgements. This work was supported by the National Natural Science Foundation of China (21277003 and U1301234), the Ministry of Science and Technology of China (2013CB228503), and the Science and Technology Plan of Shenzhen Municipality.

Edited by: Y. Cheng

\section{References}

Alexander, L., Julia, L., and Serger, A. N.: Chemistry of Atmospheric Brown Carbon, Chem. Rev., 115, 4335-4382, doi:10.1021/CR5006167, 2015.

Ångström, A.: On the Atmospheric Transmission of Sun Radiation and on Dust in the Air, Geografika Ann., 11, 156-166, 1929.

Arnott, W. P., Moosmuller, H., Rogers, C. F., Jin, T. F., and Bruch, R.: Photoacoustic spectrometer for measuring light absorption by aerosol: instrument description, Atmos. Environ., 33, 2845$2852,1999$. 
Arnott, W. P., Moosmuller, H., and Walker, J. W.: Nitrogen Dioxide and Kerosene-Flame Soot Calibration of Photoacoustic Instruments for Measurement of Light Absorption by Aerosols, Rev. Sci. Instrum., 71, 4545-4552, doi:10.1063/1.1322585, 2000.

Bahadur, E., Praveen, P. S., Xu, Y., and Ramanathan, V.: Solar absorption by elemental and brown carbon determined from spectral observations, P. Natl. Acad. Sci., 109, 17366-17371, 2012.

Bergstrom, R. W., Pilewskie, P., Russell, P. B., Redemann, J., Bond, T. C., Quinn, P. K., and Sierau, B.: Spectral absorption properties of atmospheric aerosols, Atmos. Chem. Phys., 7, 5937-5943, doi:10.5194/acp-7-5937-2007, 2007.

Bond, T. C.: Spectral dependence of visible light absorption by carbonaceous particles emitted from coal combustion, Geophys. Res. Lett., 28, 4075-4078, 2001.

Bond, T. C. and Bergstrom, R. W.: Light Absorption by Carbonaceous Particles: An Investigative Review, Aerosol Sci. Tech., 40, 27-67, doi:10.1080/02786820500421521, 2006.

Bond, T. C., Streets, D. G., Yarber, K. F., Nelson, S. M., Woo, J. H., and Klimont, Z.: A technology-based global inventory of black and organic carbon emissions from combustion, J. Geophys. Res., 109, D14203, doi:10.1029/2003jd003697, 2004.

Chakrabarty, R. K., Moosmuller, H., Chen, L. W. A., Lewis, K., Arnott, W. P., Mazzoleni, C., Dubey, M. K., Wold, C. E., Hao, W. M., and Kreidenweis, S. M.: Brown carbon in tar balls from smoldering biomass combustion, Atmos. Chem. Phys., 10, 63636370, doi:10.5194/acp-10-6363-2010, 2010.

Chakrabarty, R. K., Arnold, I. J., Francisco, D. M., Hatchett, B., Hosseinpour, F., Loria, M., Pokharel, A., and Woody, B. M.: Black and brown carbon fractal aggregates from combustion of two fuels widely used in Asian rituals, J. Quant. Spectrosc. Ra., 122, 25-30, doi:10.1016/j.jqsrt.2012.12.011, 2013.

Chakrabarty, R. K., Pervez, S., Chow, J. C., Watson, J. G., Dewangan, S., Robles, J., and Tian, G. X.: Funeral Pyres in South Asia: Brown Carbon Aerosol Emissions and Climate Impacts, Environ. Sci. Technol. Lett., 1, 44-48, doi:10.1021/ez4000669, 2014.

Chen, Y. and Bond, T. C.: Light absorption by organic carbon from wood combustion, Atmos. Chem. Phys., 10, 1773-1787, doi:10.5194/acp-10-1773-2010, 2010.

Chung, C. E., Kim, S. W., Lee, M., Yoon, S. C., and Lee, S.: Carbonaceous aerosol AAE inferred from in-situ aerosol measurements at the Gosan $\mathrm{ABC}$ super site, and the implications for brown carbon aerosol, Atmos. Chem. Phys., 12, 6173-6184, doi:10.5194/acp-12-6173-2012, 2012a.

Chung, C. E., Ramanathan, V., and Decremer, D.: Observationally constrained estimates of carbonaceous aerosol radiative forcing, P. Natl. Acad. Sci., 109, 11624-11629, 2012b.

Clarke, A., McNaughton, C., Kapustin, V., Shinozuka, Y., Howell, S., Dibb, J., Zhou, J., Anderson, B., Brekhovskikh, V., Turner, H., and Pinkerton, M.: Biomass Burning and Pollution Aerosol over North America: Organic Components and Their Influence on Spectral Optical Properties and Humidification Response, J. Geophys. Res., 112, D12S18, doi:10.1029/2006jd007777, 2007.

DeCarlo, P. F., Kimmel, J. R., Trimborn, A., Northway, M. J., Jayne, J. T., Aiken, A. C., Gonin, M., Fuhrer, K., Horvath, T., Docherty, K. S., Worsnop, D. R., and Jimenez, J. L.: Field-Deployable, High-Resolution Time-of-Flight Aerosol Mass Spectrometer, Anal. Chem., 78, 8281-8289, 2006.

Drewnick, F., Hings, S. S., DeCarlo, P., Jayne, J. T., Gonin, M., Fuhrer, K., Weimer, S., Jimenez, J. L., Demerjian, K. L., Bor- rmann, S., and Worsnop, D. R.: A new time-of-flight aerosol mass spectrometer (TOF-AMS) - Instrument description and first field deployment, Aerosol. Sci. Tech., 39, 637-658, 2005.

Einfeld, W., Ward, D. E., and Hardy, C.: Effects of fire behavior on prescribed fire smoke characteristics: A case study, in: Global biomass burning: Atmospheric, climatic, and biospheric implications, MIT Press, Cambridge, MA, USA, 412-419, 1991.

Favez, O., Alfaro, S. C., Sciare, J., Cachier, H., and Abdelwahab, M. M.: Ambient measurements of light-absorption by agricultural waste burning organic aerosols, J. Aerosol. Sci., 40, 613-620, 2009.

Feng, Y., Ramanathan, V., and Kotamarthi, V. R.: Brown carbon: a significant atmospheric absorber of solar radiation?, Atmos. Chem. Phys., 13, 8607-8621, doi:10.5194/acp-13-8607-2013, 2013.

Gadhavi, H. and Jayaraman, A.: Absorbing aerosols: contribution of biomass burning and implications for radiative forcing, Ann Geophys., 28, 103-111, doi:10.5194/angeo-28-103-2010, 2010.

Gong, Z. H., Lan, Z. J., Xue, L., Zeng, L. W., He, L. Y., and Huang, $X$. F.: Characterization of submicron aerosols in the urban outflow of the central Pearl River Delta region of China, Environ. Sci. Eng., 6, 725-733, 2012.

Gyawali, M., Arnott, W. P., Lewis, K., and Moosmüller, H.: In situ aerosol optics in Reno, NV, USA during and after the summer 2008 California wildfires and the influence of absorbing and non-absorbing organic coatings on spectral light absorption, Atmos. Chem. Phys., 9, 8007-8015, doi:10.5194/acp-9-8007-2009, 2009.

Hansen, J., Sato, M., and Ruedy, R.: Radiative forcing and climate response, J. Geophys. Res., 102, 6831-6864, 1997.

Haywood, J. M., Roberts, D. L., Slingo, A., Edwards, J. M., and Shine, K. P.: General circulation model calculations of the direct radiative forcing by anthropogenic sulfate and fossil-fuel soot aerosol, J. Climate., 10, 1562-1577, 1997.

He, L.-Y., Lin, Y., Huang, X.-F., Guo, S., Xue, L., Su, Q., Hu, M., Luan, S.-J., and Zhang, Y.-H.: Characterization of highresolution aerosol mass spectra of primary organic aerosol emissions from Chinese cooking and biomass burning, Atmos. Chem. Phys., 10, 11535-11543, doi:10.5194/acp-10-11535-2010, 2010.

He, L. Y., Huang, X. F., Xue, L., Hu, M., Lin, Y., Zheng, J., Zhang, R. Y., and Zhang, Y. H.: Submicron aerosol analysis and organic source apportionment in an urban atmosphere in Pearl River Delta of China using high-resolution aerosol mass spectrometry, J. Geophys. Res., 116, D12304, doi:10.1029/2010JD014566, 2011.

He, M., Zheng, J. Y., Yin, S. S., and Zhang, Y. Y.: Trends, temporal and spatial characteristics, and uncertainties in biomass burning emissions in the Pearl River Delta, China, Atmos. Environ., 45, 4051-4059, doi:10.1016/j.atmosenv.2011.04.016, 2011.

Huang, X. F., Yu, J. Z., He, L. Y., and Hu, M.: Size distribution characteristics of elemental carbon emitted from Chinese vehicles: results of a tunnel study and atmospheric implications, Environ. Sci. Technol., 40, 5355-5360, doi:10.1021/es0607281, 2006.

Huang, X.-F., He, L.-Y., Hu, M., Canagaratna, M. R., Kroll, J. H., Ng, N. L., Zhang, Y.-H., Lin, Y., Xue, L., Sun, T.-L., Liu, X.-G., Shao, M., Jayne, J. T., and Worsnop, D. R.: Characterization of submicron aerosols at a rural site in Pearl River Delta of China using an Aerodyne High-Resolution Aerosol Mass Spectrometer, 
Atmos. Chem. Phys., 11, 1865-1877, doi:10.5194/acp-11-18652011, 2011.

Huang, X. F., Sun, T. L., Zeng, L. W., Yu, G. H., and Luan, S. J.: Black carbon aerosol characterization in a coastal city in South China using a single particle soot photometer, Atmos. Environ., 51, 21-28, 2012.

Huang, X. F., Yun, H., Gong, Z. H., Li, X., He, L. Y., Zhang, Y. H., and Hu, M.: Source apportionment and secondary organic aerosol estimation of $\mathrm{PM}_{2.5}$ in an urban atmosphere in China, Sci. China: Earth Sci., 57, 1352-1362, 2014.

Jacobson, M. Z.: Isolating nitrated and aromatic aerosols and nitrated aromatic gases as sources of ultraviolet light absorption, J. Geophys. Res., 104, 3527-3542, 1999.

Jacobson, M. Z.: Strong radiative heating due to the mixing state of black carbon in atmospheric aerosols, Nature, 409, 695-697, 2001.

Jayne, J. T., Leard, D. C., Zhang, X. F., Davidovits, P., Smith, K. A., Kolb, C. E., and Worsnop, D. R.: Development of an aerosol mass spectrometer for size and composition analysis of submicron particles, Aerosol. Sci. Tech., 33, 49-70, 2000.

Jethva, H. and Torres, O.: Satellite-based evidence of wavelengthdependent aerosol absorption in biomass burning smoke inferred from Ozone Monitoring Instrument, Atmos. Chem. Phys., 11, 10541-10551, doi:10.5194/acp-11-10541-2011, 2011.

Jimenez, J. L., Jayne, J. T., Shi, Q., Kolb, C. E., Worsnop, D. R., Yourshaw, I., Seinfeld, J. H., Flagan, R. C., Zhang, X. F., Smith, K. A., Morris, J. W., and Davidovits, P.: Ambient aerosol sampling using the Aerodyne Aerosol Mass Spectrometer, J. Geophys. Res., 108, 8425, doi:10.1029/2001JD001213, 2003.

Kirchstetter, T. W., Novakov, T., and Hobbs, P. V.: Evidence that the spectral dependence of light absorption by aerosols is affected by organic carbon, J. Geophys. Res., 109, D21208, doi:10.1029/2004JD004999, 2004.

Koch, D. and Hansen, J.: Distant origins of Arctic black carbon: a Goddard Institute for Space Studies ModelE experiment, J. Geophys. Res., 110, D04204, doi:10.1029/2004jd005296, 2005.

Lack, D. A. and Langridge, J. M.: On the attribution of black and brown carbon light absorption using the Ångström exponent, Atmos. Chem. Phys., 13, 10535-10543, doi:10.5194/acp13-10535-2013, 2013.

Lack, D. A., Langridge, J., Richardson, M., Cappa, C. D., Law, D., and Murphy, D. M.: Aircraft instrumentation for comprehensive characterization of aerosol optical properties, Part 2: Black and brown carbon absorption and absorption enhancement measured with photo acoustic spectroscopy, Aerosol Sci. Tech., 46, 555568, 2012a.

Lack, D. A., Langridge, J. M., Bahreini, R., Cappa, C. D., Middlebrook, A. M., and Schwarz, J. P.: Brown carbon and internal mixing in biomass burning particles, P. Natl. Acad. Sci. USA. 109, 14802-14807, doi:10.1073/pnas.1206575109, 2012b.

Lan, Z. J.: Characteristics of mixing state and light absorption of black carbon aerosol in China, PhD dissertation, Peking University, Peking, 2013.

Lan, Z. J., Chen, D. L., Li, X., Huang, X. F., He, L. Y., Deng, Y. G., Feng, N., and Hu, M.: Modal characteristics of carbonaceous aerosol size distribution in an urban atmosphere of South China, Atmos. Res., 100, 51-60, 2011.

Lan, Z. J., Huang, X. F., Yu, K. Y., Sun, T. L., Zeng, L. W., and Hu, M.: Light absorption of black carbon aerosol and its enhance- ment by mixing state in an urban atmosphere in South China, Atmos. Environ., 69, 118-123, 2013.

Levin, E. J. T., McMeeking, G. R., Carrico, C. M., Mack, L. E., Kreidenweis, S. M., Word, C. E., Moosmuller, H., Arnott, W. P., Hao, W. M., Cottett Jr., J. L., and Malm, W. C.: Biomass burning smoke aerosol properties measured during Fire Laboratory at Missoula Experiments (FLAME), J. Geophys. Res.-Atmos., 115, D182010, doi:10.1029/2009JD013601, 2010.

Lewis, K., Arnott, W. P., Moosmuller, H., and Wold, C. E.: Strong spectral variation of biomass smoke light absorption and single scattering albedo observed with a novel dual-wavelength photoacoustic instrument, J. Geophys. Res., 113, D16203, doi:10.1029/2007JD009699, 2008.

Nakayama, T., Ikeda, Y., Sawada, Y., Setoguchi, Y., Ogawa, S., Kawana, K., Mochida, M., Ikemori, F., Matsumoto, K., and Matsumi, Y.: Properties of light-absorbing aerosols in the Nagoya urban area, Japan, in August 2011 and January 2012: Contributions of brown carbon and lensing effect, J. Geophys. Res.-Atmos., 119, 12721-12739, doi:10.1002/2014JD021744, 2014.

Nakayama, T., Suzuki, H., Kagamitani, S., and Ikeda, Y.: Characterization of a three wavelength photoacoustic soot spectrometer (PASS-3) and photoacoustic extinctiometer (PAX), J. Meteorol. Soc. Jpn., 93, 285-308, doi:10.2151/jmsj.2015-016, 2015.

Ng, N. L., Herndon, S. C., Trimborn, A., Canagaratna, M. R., Croteau, P. L., Onasch, T. B., Sueper, D., Worsnop, D. R., Zhang, Q., Sun, Y. L., and Jayne, J. T.: An Aerosol Chemical Speciation Monitor (ACSM) for routine monitoring of the composition concentrations of ambient aerosol, Aerosol Sci. Tech., 45, 770-784, 2011.

Patterson, E. M. and McMahon, C. K.: Absorption characteristics of forest fire particulate matter, Atmos. Environ., 18, 2541-2551, 1984.

Poschl, U.: Atmospheric Aerosols: Composition, Transformation, Climate, and Health Effects, Atoms. Chem., 44, 7520-7540, 2005.

Ramanathan, V. and Carmichael, G.: Global and regional climate changes due to black carbon, Nat. Geosci., 1, 221-227, 2008.

Ramanathan, V., Ramana, M. V., Roberts, G., Kim, D., Corriganm, C., Chung, C., and Winker, D.: Warming trends in Asia amplified by brown cloud solar absorption, Nature, 448, 575-578, doi:10.1038/nature06019, 2007.

Sandradewi, J., Prevot, A. S. H., Weingartner, E., Schmidhauser, R., Gysel, M., and Baltensperger, U.: A study of wood burning and traffic aerosols in an Alpine valley using a multi-wavelength Aethalometer, Atmos. Environ., 42, 101-111, 2008.

Scarnato, B. V., Vahidinia, S., Richard, D. T., and Kirchstetter, T. W.: Effects of internal mixing and aggregate morphology on optical properties of black carbon using a discrete dipole approximation model, Atmos. Chem. Phys., 13, 5089-5101, doi:10.5194/acp-13-5089-2013, 2013.

Schmid, O., Artaxo, P., Arnott, W. P., Chand, D., Gatti, L. V., Frank, G. P., Hoffer, A., Schnaiter, M., and Andreae, M. O.: Spectral light absorption by ambient aerosols influenced by biomass burning in the Amazon Basin. I: Comparison and field calibration of absorption measurement techniques, Atmos. Chem. Phys., 6, 3443-3462, doi:10.5194/acp-6-3443-2006, 2006.

Streets, D. G., Gupta, S., Waldhoff, S. T., Wang, M. Q., Bond, T. C., and Bo, Y. Y.: Black carbon emissions in China, Atmos. Environ., 35, 4281-4296, 2001. 
Sun, H., Biedermann, L., and Bond, T. C.: Color of brown carbon: A model for ultraviolet and visible light absorption by organic carbon aerosol, Geophys. Res. Lett., 34, L17813, doi:10.1029/2007GL029797, 2007.

Utry, N., Ajtai, T., Pinter, M., Torok, Z., Bozoki, Z., and Szabo, G.: Correlations between absorption Angström exponent (AAE) of wintertime ambient urban aerosol and its physical and chemical properties, Atmos. Environ., 91, 52-59, doi:10.1016/j.atmosenv.2014.03.047, 2014

Venkataraman, C., Habib, G., Kadamba, D., Shrivastava, M., Leon, J.-F., Crouzille, B., Boucher, O., and Streets, D. G.: Emissions from open biomass burning in India: Integrating the inventory approach with high-resolution Moderate Resolution Imaging Spectroradiometer (MODIS) active-fire and land cover data, Global Biogeochem. Cy., 20, GB2013, doi:10.1029/2005GB002547, 2006.

Wang, X., Heald, C. L., Ridley, D. A., Schwarz, J. P., Spackman, J. R., Perring, A. E., Coe, H., Liu, D., and Clarke, A. D.: Exploiting simultaneous observational constraints on mass and absorption to estimate the global direct radiative forcing of black carbon and brown carbon, Atmos. Chem. Phys., 14, 10989-11010, doi:10.5194/acp-14-10989-2014, 2014.

Washenfelder, R. A., Attword, A. R., Brock, C. A., Guo, H., Xu, L., Weber, R. J., Ng, N. L., Allen, H. M., Ayres, B. R., Baumann, K., Cohen, R. C., Draper, D. C., Duffey, K. C., Edgerton, E., Fry, J. L., Hu, W. W., Jimenez, J. L., Palm, B. B., Romer, P., Stone, E. A., Wooldridge, P. J., and Brown, S. S.: Biomass burning dominates brown carbon absorption in the rural southeastern United States, Geophys. Res. Lett., 42, 653-664, doi:10.1002/2014GL062444, 2015.
Yan, X. Y., Ohara, T., and Akimoto, H.: Bottom-up estimate of biomass burning in mainland China, Atmos. Environ., 40, 52625273, doi:10.1016/j.atmosenv.2006.04.040, 2006.

Yang, M., Howell, S. G., Zhuang, J., and Huebert, B. J.: Attribution of aerosol light absorption to black carbon, brown carbon, and dust in China - interpretations of atmospheric measurements during EAST-AIRE, Atmos. Chem. Phys., 9, 2035-2050, doi:10.5194/acp-9-2035-2009, 2009.

Yuan, Z. B., Lau, A. K. H., Zhang, Y. H., Yu, J. Z., Louie, P. K. K., and Fung, J. C. H.: Identification and spatiotemporal variations of dominant $\mathrm{PM}_{10}$ sources over Hong Kong, Atmos. Environ., 40, 1803-1815, 2006.

Zhang, Y. S., Shao, M., Lin, Y., Luan, S. J., Mao, N., Chen, W. T., and Wang, M.: Emission inventory of carbonaceous pollutants from biomass burning in the Pearl River Delta Region, China, Atmos. Environ., 76, 189-199, doi:10.1016/j.atmosenv.2012.05.055, 2013. 